\title{
The Role of Bacillus amyloliquefaciens on Litopenaeus vannamei During the Maturation of a Biofloc System
}

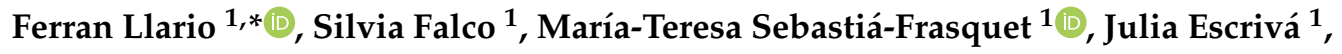 \\ Miguel Rodilla ${ }^{1}$ and Luís Henrique Poersch ${ }^{2}$ \\ 1 Institut d'Investigació per a la Gestió Integrada de Zones Costaners (IGIC), Universitat Politècnica de \\ València (UPV), Paranimf, 1., Grau de Gandia, 46730 València, Spain \\ 2 Estação Marinha de Aquacultura, Instituto de Oceanografia, Universidade Federal do Rio Grande (FURG), \\ Rio Grande, Rio grande do Sul 474, Brazil \\ * Correspondence: ferllase@upv.es
}

Received: 14 June 2019; Accepted: 16 July 2019; Published: 18 July 2019

\begin{abstract}
Biofloc technology is a sustainable aquaculture production system which uses microorganisms to maintain water quality and to increase productivity. In this system, probiotics can enhance the positive effects of bioflocs on the cultured species. The objective of this research is to study the role of the probiotic bacterium Bacillus amyloliquefaciens during the formation of a biofloc system for the culture of Litopenaeus vannamei. Two doses of probiotic were assayed and applied directly to the water. The experiment was developed in nine tanks distributed as follows: Three control tanks with no probiotic, three tanks with a probiotic dose of $10^{3} \mathrm{cfu} / \mathrm{mL}$, and three tanks with a dose of $10^{4} \mathrm{cfu} / \mathrm{mL}$. Water quality, microbial activity, growth parameters and the immune system state of shrimps were monitored throughout the maturation process. The results indicate a positive effect upon the shrimp immune system throughout the study period, where specifically there was an increase in granular hemocytes in the shrimp hemolymph. During the immature biofloc phase, granular hemocytes were $5 \%$ higher in tanks supplemented with the probiotic. During the mature biofloc phase, granular hemocytes were $7 \%$ higher in those same tanks. During the maturation of the biofloc, environmental conditions are more unfavorable for shrimp growth, due to the accumulation of nitrites. So, the effect of the probiotic is especially important during this stage when the shrimp are stressed and are more vulnerable to diseases. However, the effects on microbial activity, water quality and Litopenaeus vannamei growth did not increase the benefits of the biofloc system.
\end{abstract}

Keywords: growth parameters; immune system; microbiological activity; probiotic; shrimp; water quality; white shrimp

\section{Introduction}

Biofloc technology (BFT) is considered a sustainable aquaculture production system because it reduces water renewal needs thanks to the activity of microorganisms [1,2]. In BFT systems, we can find different microorganisms, such as bacteria, phytoplankton, rotifers, protozoans and copepods [3], which interact with the nutrients and organic matter present in water and form bioflocs [3,4]. The bioflocs are formed because the organic matter (unconsumed feed, dead organisms, old exoskeletons of shrimp, etc.) and the microorganisms (bacteria, phytoplankton, rotifers, etc.) tend to agglutinate. Bacteria are the most important microorganisms for the maintenance of water quality because they eliminate the majority of nitrogen compounds present in the water column $[1,3,4]$. The most abundant bacteria in aquaculture systems are heterotrophic and autotrophic bacteria [1-3].

On the one hand, heterotrophic bacteria remove nitrogen compounds dissolved in water more efficiently than autotrophic bacteria [1]. Nitrogen compounds are converted into microbial protein 
which can be consumed by the cultured species, such as shrimps [1-3]. On the other hand, autotrophic bacteria oxidize nitrogen compounds [1-3]. The bacteria are responsible for the maturation process, because they are in charge of controlling the nitrogen compounds at safe levels for shrimp $[5,6]$. The maturation process of BFT systems has two stages. First, the immature state is characterized by no bacteria community and the accumulation of ammonium and nitrite. Second, when the bacteria community develops, the system is mature, and ammonium and nitrite are oxidized quickly. In this later stage nitrate accumulates in the water $[5,6]$. Elimination of the nitrogen compounds, fundamentally ammonia and nitrite, is the main reason why BFT systems have been considered as an environmentally friendly aquaculture technique, because the heterotrophic bacteria maintain these nutrients under low concentration [1]. In addition, these bacteria compete for resources and space with pathogens, and have a probiotic effect upon shrimps. Probiotics are any live microorganisms that, when administered in adequate amounts, confer a health benefit upon the host [7]. BFT systems, also allow increasing the farming density, being more productive than traditional aquaculture systems [4].

Probiotics are live microorganisms, which may reduce the probability of some pathogens to affect the shrimps [8]. Currently, some farmers frequently apply medicines and antibiotics as preventive treatments [8] with no dose assays, which can end in overdoses. The use of probiotics can be an alternative to preventive medicine [8]. The abundance of heterotrophic bacteria in BFT systems decreases the probability of pathogens proliferation and it affects positively the immune system of the shrimps [3,9]. The addition of probiotics are usually used preventively [8] or for the treatment of pathogens [10], and it can help the cultured species to better resist the stress produced by adverse conditions, such as those produced during the maturation of biofloc systems $[3,5,11]$. Probiotics are characterized by distinctive action mechanisms [8]: (1) Enzyme production in the host intestine, which increases the digestibility of the food and improves the growth of the host [12,13]; (2) the production of bactericidal compounds inside the host [14]; (3) a stimulation of the host immune system, which makes it more resistant to pathogens $[15,16] ;$ (4) competition with the rest of the bacteria for resources, which can diminish the presence of pathogens [17,18]; and (5) a maintenance of water quality; probiotics consume nitrogen compounds, such as nitrites and ammonia, which are toxic to cultured species $[19,20]$. In cultured shrimp, the dose of the probiotic dissolved in water depends on the species and culture conditions. Doses from $10^{3}$ to $10^{8} \mathrm{cfu} \mathrm{mL}^{-1}$ are the most usual $[8,9,12,21]$.

Biofloc technology is being developed mostly in farms in North America, South America and Asia [1], where there is an important tradition of shrimp farming. In Europe, this technology has started to develop recently. One of the main disadvantages of shrimp farms in the European Union (EU) is the limited choice of any products marketed, specifically to develop the aquaculture activity, such as feed and probiotics. The low number of BFT shrimp farms in this region has discouraged European manufacturers. Moreover, importing these products from other world regions such as America or Asia is difficult. European Union legislation is strict, especially for probiotics, because they are live microorganisms, and their importation requires different controls and certificates to avoid introducing foreign diseases. This demands expensive administrative procedures, which are not profitable for distribution companies, due to the small sales volume in the European Union.

The probiotic Ecobiol Plus ${ }^{\circledR}$ is composed of the bacterium Bacillus amyloliquefaciens, and it is marketed in the European Union, to be used in chickens and pigs [22-25]. Different experiences have shown that it also has positive effects in aquaculture water recirculation systems [13,26-29]. However, BFT aquaculture systems conditions are strongly different, and the Ecobiol Plus ${ }^{\circledR}$ has not been tested during the maturation of a biofloc system.

The objective of this research is to study the role of the probiotic bacterium B. amyloliquefaciens during the maturation process of a biofloc system. We studied its effect on the biofloc system (water quality dynamics, trophic state development and microbial activity evolution), and on cultured shrimps (growth parameters and the immune system). 


\section{Materials and Methods}

\subsection{Location and Shrimp Culture System}

The experiment was developed in the Universitat Politècnica de València facilities (Grau de Gandia, Spain), during 169 days, between 11 May (end of spring) and 16 October (early autumn) 2016. Postlarvae white shrimp (PL) were purchased from a commercial laboratory (Shrimp Improvement Systems, FL, USA), and they were certificated as free of pathogens. This certificate guarantees that the shrimp are not infected by the principal diseases as Taura syndrome, white spot disease and yellow head disease, among others [30,31]. PLs of $0.07 \pm 0.04 \mathrm{~g}$ weight were distributed within nine square tanks filled with $2250 \mathrm{~L}$ of water and with a surface area of $3.2 \mathrm{~m}^{2}$ for each tank. The shrimp density was 200 individuals $/ \mathrm{m}^{2}$. Each tank was filled with a mixture of seawater and freshwater which had a salinity level of $22.5 \mathrm{~g} / \mathrm{L}$. The water was disinfected with $10 \mathrm{mg} / \mathrm{L}$ of chlorine, which was subsequently eliminated by adding $1 \mathrm{mg} / \mathrm{L}$ of ascorbic acid to the tanks [10]. The tanks were located in a greenhouse and were constantly individually aerated. Every day the shrimp were fed with commercial feed (Le Gouessant) specifically designed for L. vannamei. Fortnightly, this feed amount was calculated according to the shrimp estimated biomass (calculated each 15 days) and the daily water temperature, according to Jory et al. [31]. Feeding was provided twice a day, $40 \%$ in the morning and $60 \%$ in the afternoon, and it was placed into feed trays.

The following water quality parameters were monitored: Salinity, temperature, $\mathrm{pH}$, alkalinity, dissolved oxygen, nutrients and total suspended solids (TSS). Dissolved oxygen (DO), salinity and temperature were monitored in situ, using two parameter probes (YSI ProODO and WTW Multi 340i respectively), twice a day. The $\mathrm{pH}$ was measured once a day using pHMeter BASIC 20+, the Crison. Alkalinity was analyzed after the first month of culture, every two weeks, by titration with hydrochloric acid [31]. Every two days an aliquot of water was collected to determine the concentration of the total dissolved ammonia (N-TA mg/L) using the methodology described by Baumgarten et al. [32], nitrites ( $\left.\mathrm{N}^{-\mathrm{NO}_{2}}{ }^{-} \mathrm{mg} / \mathrm{L}\right)$, using the methodology of Bendschneider and Robinson described in Baumgarten et al. [32] and the nitrates $\left(\mathrm{N}^{-N}{ }_{3}{ }^{-} \mathrm{mg} / \mathrm{L}\right)$ were analyzed following the methodology described by Grasshof [33]. In addtion, phosphates ( ${\mathrm{P}-\mathrm{PO}_{4}}^{3-} \mathrm{mg} / \mathrm{L}$ ) were analyzed following the colorimetric reaction described by Murphy and Riley [34]. The TSS was analyzed once a week as described by Baumgarten et al. [32].

Due to evaporation, salinity can increase above to $22.5 \mathrm{~g} / \mathrm{L}$, so in this case freshwater was added to keep salinity under this threshold. Different shade cloths were used to control the greenhouse temperature, in order to keep the water temperature within the optimal range for shrimp culture according to Van Wyk and Scarpa [35]. At the beginning of the study period (5 May) the greenhouse roof was covered with a white shade cloth. On day 59 (8 July), the shade cloth was substituted by a black one. Finally, on day 136 (23 September), the black shade cloth was removed, due to a lower environmental temperature at the end of summer and the beginning of autumn. The evolution of maximum and minimum daily environmental temperature was recorded from the data of the weather station of the Reial Club Nàutic de Gandia [36]. The $\mathrm{pH}$ was maintained between 7 and 9 (slightly alkali) [35]. We added $0.15 \mathrm{mg} / \mathrm{L}$ of calcium hydroxide when $\mathrm{pH}$ values below 7.50 were detected [37]. Alkalinity was maintained above $50 \mathrm{mg} \mathrm{CaCO} / \mathrm{L}$ [34]. Also, we added $0.20 \mathrm{~g} / \mathrm{L}$ of sodium bicarbonate when alkalinity below $120 \mathrm{mg} \mathrm{CaCO} / \mathrm{L}$ was observed [38].

The initial fertilization of the system was done with sucrose $(15 \mathrm{mg} / \mathrm{L}$ of carbon), to facilitate the initial development of heterotrophic bacteria. During the experiment, sucrose was added, in a ratio C:N-TA of 15:1, when the ammonia, produced by the shrimps and organic matter, reached a concentration greater than $1 \mathrm{mg} / \mathrm{L}$ [2,39]. Eventual renewal of the water during the experiment was minimal, and was performed when the nitrite level reached $15 \mathrm{mg} / \mathrm{L}$, in order to avoid the toxic effects of nitrites [40]. When we detected a toxic concentration of nitrite (higher than $15 \mathrm{mg} / \mathrm{L}$ ) in a tank, we renewed between $10 \%$ and $15 \%$ of the water (between days 56 and 80 ). At the end of experimental 
period the total renewal water was $25 \%$ in all of the tanks. Between days 35 and 100, the feed was reduced by $40 \%$ in order to minimize the contribution of nitrogen to the system.

\subsection{Probiotic Treatments}

During the experiment, the probiotic Ecobiol Plus ${ }^{\circledR}$ was used, with a certified content by the manufacturer of $1.3 \times 10^{10} \mathrm{cfu} / \mathrm{g}$ of viable spores of B. amyloliquefaciens in powder form. The experiment was developed in nine tanks distributed as follows: Three control tanks with no probiotic (control treatment), three tanks with a probiotic dose of $10^{3} \mathrm{cfu} / \mathrm{mL}$ (low bacteria treatment) and three tanks with a dose of $10^{4} \mathrm{cfu} / \mathrm{mL}$ (high bacteria treatment). The probiotic was applied directly to the water every day.

\subsection{Chlorophyll a and Microbial Activity}

To determine chlorophyll $a(\mathrm{Chl} a)$, an aliquot of water was filtered on a glass fiber filter $(25 \mathrm{~mm} \varnothing)$ and ultra-frozen $\left(-86^{\circ} \mathrm{C}\right)$. Subsequentl the pigments were extracted with acetone high-performance liquid chromatography (HPLC) grade. Chlorophyll $a$ was measured by HPLC, according to the method of Wright et al. [41], modified by Hooker et al. [42]. Microbial activity was analyzed once a week during the whole experiment. The method of dark and transparent bottles of Strickland adapted by Schveitzer et al. [43] was used. Six bottles of $100 \mathrm{~mL}$ ( 3 dark and 3 transparent) were placed in each tank five centimeters below the water surface. To keep the bioflocs in suspension inside the bottles, they were shaken manually every $20 \mathrm{~min}$, following the methodology of Schveitzer et al. [43]. The bottles were incubated for approximately $8 \mathrm{~h}$. Dissolved oxygen was measured at the beginning and end of each incubation. Water column respiration (WCR), net primary productivity (NPP) and gross primary productivity (GPP) were calculated using Equations (1)-(3) following Dodds and Cole [44].

$$
\begin{gathered}
\operatorname{WCR}\left(\mathrm{mg} \mathrm{O}_{2} /(\mathrm{L} \cdot \mathrm{h})\right)=\frac{\text { initial } \mathrm{O}_{2} \text { of dark bottle }- \text { final } \mathrm{O}_{2} \text { of dark bottle }}{\text { time }(\mathrm{h})} \\
\operatorname{NPP}\left(\mathrm{mg} \mathrm{O}_{2} /(\mathrm{L} \cdot \mathrm{h})\right)=\frac{{\text { final } \mathrm{O}_{2} \text { of light bottle }- \text { initial } \mathrm{O}_{2} \text { of light bottle }}_{\text {time }(\mathrm{h})}}{\operatorname{GPP}\left(\mathrm{mg} \mathrm{O}_{2} /(\mathrm{L} \cdot \mathrm{h})\right)=\mathrm{WCR}+\mathrm{NPP}}
\end{gathered}
$$

\subsection{Growth Parameters}

An initial biometry was performed on 100 PLs with a balance (Kern ABT 220-4M; \pm 0.0001 ). Biometry of 30 shrimps per tank was done every two weeks with a balance (Kern EW600-2M; \pm 0.01 ) to monitor growth and adjust the dose of feed required. At the end of the experiment, the number of shrimps was counted, and 50 shrimps per tank were weighed. We calculated weight gain, weekly weight gain, final biomass, biomass increase, feed conversion rate (FCR) and survival with the following equations (Equations (4)-(9)).

$$
\begin{gathered}
\text { Weight gain }(\mathrm{g})=\text { final wet weight }- \text { initial wet weight } \\
\text { Weekly weight gain }(\mathrm{g} / \text { week })=\frac{\text { weight gain }}{\text { number of weeks }} \\
\text { Biomass }\left(\frac{\mathrm{g}}{\mathrm{m}^{2}}\right)=\frac{\text { wet weight shrimp } \times \text { number of shrimp }}{\mathrm{m}^{2}} \\
\text { Biomass gain }\left(\mathrm{g} / \mathrm{m}^{2}\right)=\text { final biomass }- \text { initial biomass } \\
\text { Feed conversion rate }=\frac{\text { dry feed consumption }}{\text { weight gain }}
\end{gathered}
$$




$$
\text { Survival }(\%)=\frac{\text { final shrimp amount }}{\text { initial shrimp amount }} \times 100
$$

\subsection{Immune Parameters}

The state of the shrimp immune system was determined in the middle of the experiment (day 86), when the system was immature, and at the end of the experiment (day 169), when the system had completed its maturation process. For the analysis of the immune system, hemolymph was collected from five shrimps per tank with a sterile syringe BD Plastipak ${ }^{\circledR}$, which is the minimum number of samples recommended for this analysis (three to eight shrimp per tank) [45-49]. The sample was divided into two aliquots. The first aliquot of $20 \mu \mathrm{L}$ was mixed with $80 \mu \mathrm{L}$ of Alsever solution, to determine the percentage of granular $(\mathrm{GH})$ and hyaline $(\mathrm{HH})$ hemocytes (with an approximate diameter of 10-15 $\mu \mathrm{m}$ ), using a Bürker chamber and a Leica DM 2500 microscope [50]. The second aliquot of $500 \mu \mathrm{L}$ was allowed to coagulate for $2 \mathrm{~h}$ at $4{ }^{\circ} \mathrm{C}$. Then it was centrifuged at $2000 \times g$ to extract the serum, which was frozen [50]. Subsequently, the total protein concentration (TPC) was analyzed using the method described by Lowry et al. [51].

\subsection{Statistical Analysis}

The statistical analysis was carried out using Statgraphics ${ }^{\circledR}$ Centurion XVI.I. First, the normality and homoscedasticity of all the parameters were analyzed. A univariate analysis was performed to detect significant differences according to the probiotic treatments (high bacteria, low bacteria or control) (Tables 1 and 2) in all of the variables studied. An Analysis of Variance (ANOVA) test was used for variables that followed a normal distribution, or were transformed to a normal distribution through a $\log _{10}$ or $\sqrt[2]{x}$ conversion (WCR, Chla, growth parameters and immune system parameters). The non-parametric Kruskal-Wallis test was applied to the variables with non-normal distribution (nutrients, TSS, GPP and NPP). Also, the results of the immune system parameters were compared during the different stages of maturation of the Biofloc technology (BFT) system (Table 3). The results are expressed as the average \pm standard deviation.

Table 1. Average and standard deviation of $\mathrm{pH}$, alkalinity, salinity, dissolved oxygen concentration and dissolved oxygen saturation percentage for high bacteria treatment $\left(2.8 \times 10^{4} \mathrm{cfu} / \mathrm{mL}\right)$, low bacteria treatment $\left(2.8 \times 10^{3} \mathrm{cfu} / \mathrm{mL}\right)$ and control treatment. The $n$ values are indicated for each treatment.

\begin{tabular}{cccc}
\hline & High Bacteria Treatment & Low Bacteria Treatment & Control Treatment \\
\hline $\mathbf{p H}$ & $7.77 \pm 0.39$ & $7.74 \pm 0.43$ & $7.74 \pm 0.40$ \\
& $(n=450)$ & $(n=450)$ & $(n=450)$ \\
\hline Alkalinity & $108.89 \pm 30.05$ & $96.70 \pm 27.29$ & $101.56 \pm 27.92$ \\
$(n=42)$ & $(n=42)$ & $(n=42)$ \\
\hline (mg CaCO $/ \mathbf{L})$ & $5.88 \pm 0.48$ & $5.97 \pm 0.37$ & $5.95 \pm 0.38$ \\
Dissolved oxygen & $(n=507)$ & $(n=507)$ & $(n=507)$ \\
(mg/L) & $91.4 \pm 8.38$ & $93.0 \pm 6.66$ & $93.7 \pm 7.73$ \\
\hline Dissolved oxygen & $(n=507)$ & $(n=507)$ & $(n=507)$ \\
(\%) & $22.5 \pm 0.08$ & $22.5 \pm 0.08$ & $22.5 \pm 0.07$ \\
Salinity & $(n=498)$ & $(n=498)$ & $(n=498)$ \\
(g/L) & & &
\end{tabular}


Table 2. Mean and standard deviation of the growth parameters for high bacteria treatment $\left(2.8 \times 10^{4} \mathrm{cfu} / \mathrm{mL}\right)$, low bacteria treatment $\left(2.8 \times 10^{3} \mathrm{cfu} / \mathrm{mL}\right)$ and control treatment. The $n$ values are indicated for each treatment.

\begin{tabular}{|c|c|c|c|c|}
\hline & High Bacteria Treatment & Low Bacteria Treatment & Control Treatment & $p$ \\
\hline $\begin{array}{l}\text { Weight gain } \\
\text { (g) }\end{array}$ & $\begin{array}{c}16.59 \pm 1.15 \\
(n=3)\end{array}$ & $\begin{array}{c}17.41 \pm 1.42 \\
(n=3)\end{array}$ & $\begin{array}{c}17.76 \pm 0.65 \\
(n=3)\end{array}$ & 0.33 \\
\hline $\begin{array}{l}\text { Weekly weight gain } \\
\text { (g/week) }\end{array}$ & $\begin{array}{c}0.69 \pm 0.01 \\
\quad(n=3)\end{array}$ & $\begin{array}{c}0.72 \pm 0.06 \\
\quad(n=3)\end{array}$ & $\begin{array}{c}0.73 \pm 0.03 \\
\quad(n=3)\end{array}$ & 0.33 \\
\hline $\begin{array}{l}\text { Biomass production } \\
\left(\text { ton } / \mathrm{m}^{2}\right)\end{array}$ & $\begin{array}{l}21.74 \pm 1.83 \\
\quad(n=3)\end{array}$ & $\begin{array}{c}23.00 \pm 2.67 \\
\quad(n=3)\end{array}$ & $\begin{array}{c}21.07 \pm 2.03 \\
(n=3)\end{array}$ & 0.58 \\
\hline FCR & $\begin{array}{c}1.91 \pm 0.11 \\
(n=3)\end{array}$ & $\begin{array}{c}1.81 \pm 0.15 \\
(n=3)\end{array}$ & $\begin{array}{c}1.96 \pm 0.21 \\
(n=3)\end{array}$ & 0.53 \\
\hline Survival (\%) & $\begin{array}{c}65.77 \pm 4.97 \\
(n=3)\end{array}$ & $\begin{array}{c}66.19 \pm 3.48 \\
(n=3)\end{array}$ & $\begin{array}{c}59.53 \pm 4.92 \\
(n=3)\end{array}$ & 0.21 \\
\hline
\end{tabular}

Table 3. Average and standard deviation of immune system parameters (total protein concentration (TPC), granular hemocytes $(\mathrm{GH})$ and hyaline hemocytes $(\mathrm{HH})$ ) in different stages of Biofloc technology (BFT) evolution (immature and mature BFT) for high bacteria treatment $\left(2.8 \times 10^{4} \mathrm{cfu} / \mathrm{mL}\right)$, low bacteria treatment $\left(2.8 \times 10^{3} \mathrm{cfu} / \mathrm{mL}\right)$ and control treatment. The $n$ values are indicated for each treatment.

\begin{tabular}{|c|c|c|c|}
\hline \multicolumn{4}{|c|}{ Immature Biofloc System (day 86) } \\
\hline & High Bacteria Treatment & Low Bacteria Treatment & Control Treatment \\
\hline $\begin{array}{c}\text { TPC } \\
(\mathrm{mg} / \mathrm{mL})\end{array}$ & $\begin{array}{c}93.18 \pm 3.99^{\mathrm{a}} \\
\quad(n=3)\end{array}$ & $\begin{array}{c}89.49 \pm 21.16^{\mathrm{a}} \\
\quad(n=3)\end{array}$ & $\begin{array}{c}82.58 \pm 10.10^{\mathrm{a}} \\
\quad(n=3)\end{array}$ \\
\hline $\begin{array}{l}\text { GH } \\
(\%)\end{array}$ & $\begin{array}{c}30.00 \pm 1.40^{\mathrm{a}} \\
\quad(n=3)\end{array}$ & $\begin{array}{c}31.33 \pm 3.58^{\mathrm{a}} \\
\quad(n=3)\end{array}$ & $\begin{array}{c}25.13 \pm 0.99 \mathrm{~b} \\
\quad(n=3)\end{array}$ \\
\hline $\begin{array}{r}\mathrm{HH} \\
(\%)\end{array}$ & $\begin{array}{c}70.00 \pm 1.40^{\mathrm{a}} \\
\quad(n=3)\end{array}$ & $\begin{array}{c}68.67 \pm 3.58^{\mathrm{a}} \\
\quad(n=3)\end{array}$ & $\begin{array}{c}74.87 \pm 0.99 \mathrm{~b} \\
\quad(n=3)\end{array}$ \\
\hline \multicolumn{4}{|c|}{ Mature Biofloc System (day 169) } \\
\hline & High Bacteria Treatment & Low Bacteria Treatment & Control Treatment \\
\hline $\begin{array}{c}\text { TPC } \\
(\mathrm{mg} / \mathrm{mL})\end{array}$ & $\begin{array}{c}123.14 \pm 8.82^{\mathrm{a}} \\
(n=3)\end{array}$ & $\begin{array}{c}120.62 \pm 12.26^{\mathrm{a}} \\
(n=3)\end{array}$ & $\begin{array}{c}117.75 \pm 25.60^{\mathrm{a}} \\
(n=3)\end{array}$ \\
\hline $\begin{array}{l}\text { GH } \\
(\%)\end{array}$ & $\begin{array}{c}46.66 \pm 2.80^{\mathrm{a}} \\
\quad(n=3)\end{array}$ & $\begin{array}{c}46.28 \pm 2.89^{a} \\
\quad(n=3)\end{array}$ & $\begin{array}{c}39.03 \pm 3.89^{b} \\
\quad(n=3)\end{array}$ \\
\hline $\begin{array}{c}\mathrm{HH} \\
(\%)\end{array}$ & $\begin{array}{c}53.34 \pm 2.80^{\mathrm{a}} \\
\quad(n=3)\end{array}$ & $\begin{array}{c}53.72 \pm 2.899^{a} \\
\quad(n=3)\end{array}$ & $\begin{array}{c}60.97 \pm 2.89^{b} \\
\quad(n=3)\end{array}$ \\
\hline
\end{tabular}

$\mathrm{a}$ and ${ }^{\mathrm{b}}$ superscript indicate Analysis of Variance (ANOVA) test results. Those treatments that do not share the same letter show statistically significant differences for the variable shown $(p<0.05)$.

\section{Results}

\subsection{Water Quality}

Average water temperature, as well as minimum and maximum ambient temperature values are shown along the study period (Figure 1). The change in water temperature was due to the ambient temperature variation. The water temperature ranged between an average maximum temperature of $31.0^{\circ} \mathrm{C}$ (day 35) and a minimum of $22.5^{\circ} \mathrm{C}$ (day 165). The greenhouse shade cloths were handled to avoid excessively high temperatures. Table 1 shows $\mathrm{pH}$, alkalinity, salinity and dissolved oxygen (concentration and saturation percentage) average values and the standard deviation for each treatment. The average of $\mathrm{pH}$ and alkalinity was around 7.75 and $102.38 \mathrm{mg} \mathrm{CaCO} / \mathrm{L}$, respectively. Dissolved oxygen and salinity were stable with an average around of $5.93 \mathrm{mg} / \mathrm{L}$ and $22.5 \mathrm{~g} / \mathrm{L}$, respectively. 


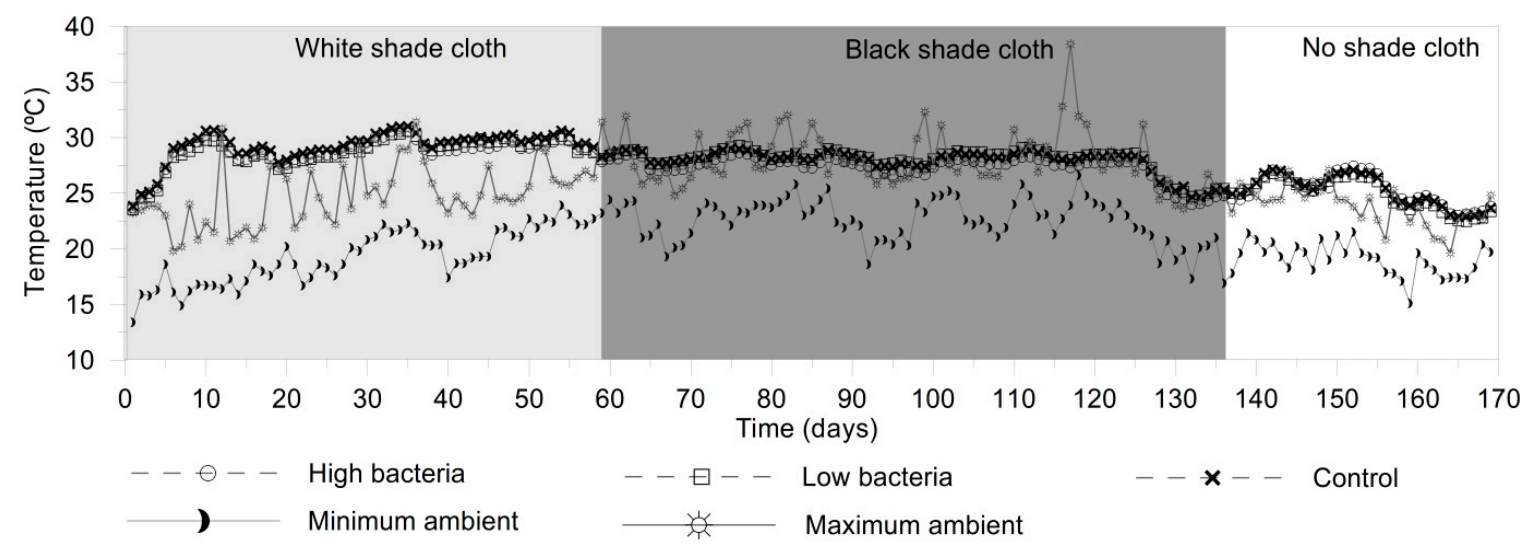

Figure 1. Evolution of water temperature, minimum and maximum ambient temperature values are shown along the study period. Each data represents the average of the three experimental units for high bacteria treatment $\left(2.8 \times 10^{4} \mathrm{cfu} / \mathrm{mL}\right)$, low bacteria treatment $\left(2.8 \times 10^{3} \mathrm{cfu} / \mathrm{mL}\right)$ and control treatment.

In water, N-TA was accumulated during the first 45 days (Figure 2a), registering maximum values of $1.44 \mathrm{mg} / \mathrm{L}$ in the low bacteria treatment and $0.89 \mathrm{mg} / \mathrm{L}$ in the high bacteria treatment and control

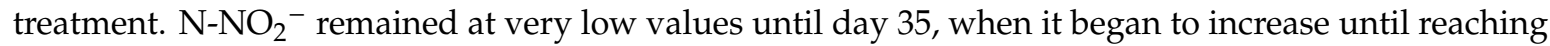
a maximum of $19.08 \mathrm{mg} / \mathrm{L}$ in the high bacteria treatment, $20.39 \mathrm{mg} / \mathrm{L}$ in the low bacteria treatment and $21.10 \mathrm{mg} / \mathrm{L}$ in our control treatment. Around day 100 , the concentrations of $\mathrm{N}^{-\mathrm{NO}_{2}}{ }^{-}$were progressively reduced, reaching very low levels since day 118 (Figure $2 \mathrm{~b}$ ). $\mathrm{N}^{-\mathrm{NO}_{3}}{ }^{-}$was first detected on day 90, and increased progressively reaching its maximum value at the end of the culture (Figure $2 \mathrm{c}$ ), when concentrations of $65.18,77.72$ and $74.54 \mathrm{mg} / \mathrm{L}$ were measured in high bacteria, low bacteria and control treatments, respectively. $\mathrm{P}_{-} \mathrm{PO}_{4}{ }^{3-}$ was accumulated in water during the entire culture (Figure $2 \mathrm{~d}$ ). The highest values were observed at the end of the culture, being $17.91,15.34$ and $13.45 \mathrm{mg} / \mathrm{L}$ in high bacteria, low bacteria and control treatment, respectively. No statistically different levels of nutrients were observed between treatments (N-TA, $p=0.11 ;{\mathrm{N}-\mathrm{NO}_{2}}^{-}, p=0.06 ;{\mathrm{N}-\mathrm{NO}_{3}}^{-}, p=0.53 ; \mathrm{P}^{-} \mathrm{PO}_{4}{ }^{3-}$, $p=0.95)$. However, a trend close to significance $(p=0.06)$ was observed for $\mathrm{N}^{-\mathrm{NO}_{2}}{ }^{-}$with higher values in the control treatment. 


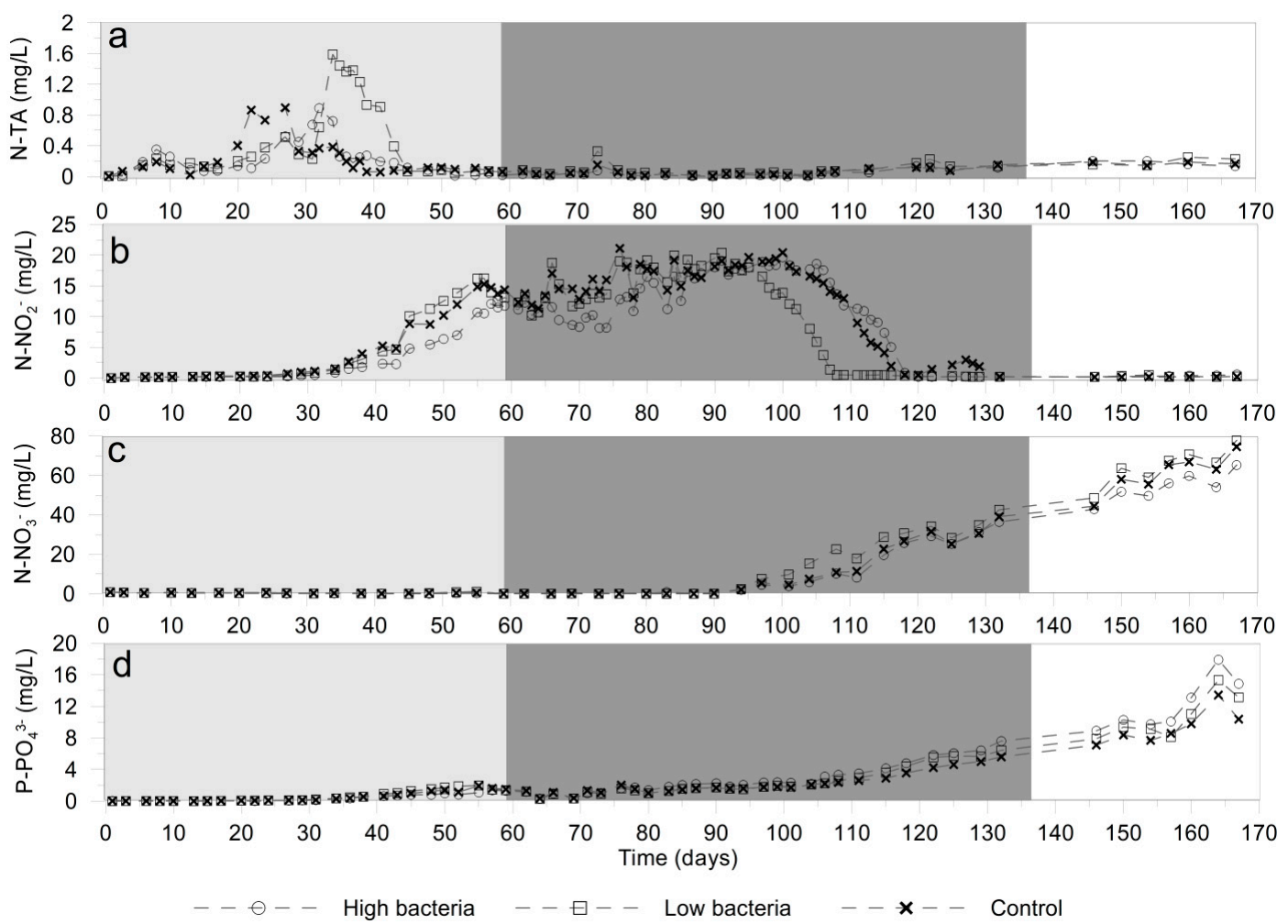

Figure 2. Evolution of nutrients, (a) total dissolved ammonia, (b) nitrites, (c) nitrates and (d) phosphates. Each data represents the average of the three experimental units for high bacteria treatment $\left(2.8 \times 10^{4} \mathrm{cfu} / \mathrm{mL}\right)$, low bacteria treatment $\left(2.8 \times 10^{3} \mathrm{cfu} / \mathrm{mL}\right)$ and control treatment. Between days 56 and 80 approximately 10 to $15 \%$ of water was renewed to avoid any toxic concentration of nitrite.

TSS was accumulated in the system during the culture period (Figure 3). The maximum average values obtained were $1.19,0.73$ and $0.67 \mathrm{~g} / \mathrm{L}$ in the high bacteria, low bacteria and control treatments, respectively. Between day 60 and day 130, small decreases were observed in TSS concentration, which were produced due to water renewal, to control the $\mathrm{N}^{-\mathrm{NO}_{2}}{ }^{-}$levels in the system.

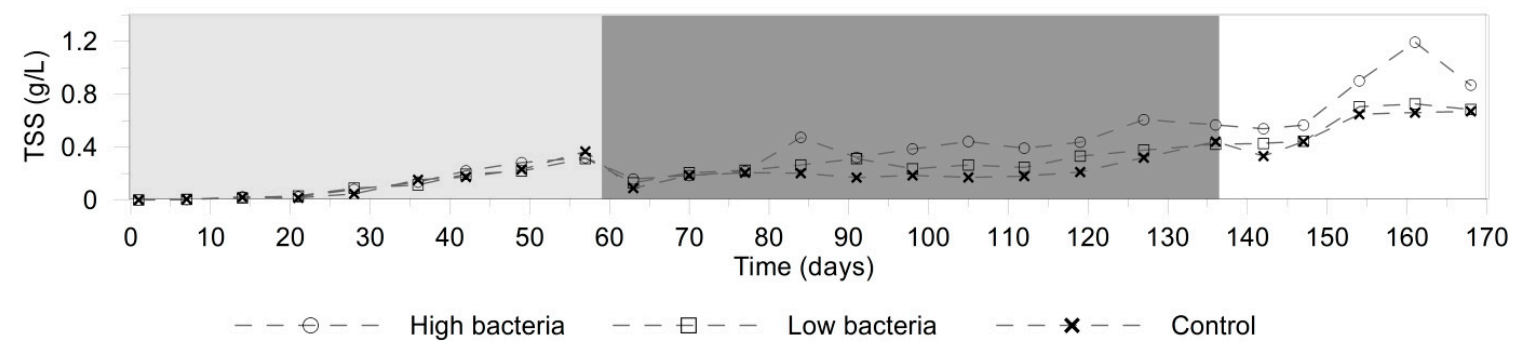

Figure 3. Evolution of total solid suspends. Each data represents the average of the three experimental units for high bacteria treatment $\left(2.8 \times 10^{4} \mathrm{cfu} / \mathrm{mL}\right)$, low bacteria treatment $\left(2.8 \times 10^{3} \mathrm{cfu} / \mathrm{mL}\right)$ and control treatment.

\subsection{Microbial Activity}

GPP was maximum during the first culture phase, where values of $1.15,0.93$ and $0.74 \mathrm{mg} \mathrm{O} /(\mathrm{L} \cdot \mathrm{h})$ were reached in high bacteria, low bacteria and control treatments, respectively; after day 58 it remained below $0.5 \mathrm{mg} \mathrm{O}_{2} /(\mathrm{L} \cdot \mathrm{h})$ in all treatments (Figure 4a).

WCR increased during the first weeks until day 35 , and then remained stable throughout the experiment, reaching its maximum on day 135 , with values of $0.44,0.45$ and $0.51 \mathrm{mg} \mathrm{O}_{2} /(\mathrm{L} \cdot \mathrm{h})$ in high 
bacteria, low bacteria and control treatments, respectively (Figure $4 \mathrm{~b}$ ). The NPP was positive during the first weeks, observing a maximum of $0.82,0.72$ and $0.61 \mathrm{mg} \mathrm{O}_{2} /(\mathrm{L} \cdot \mathrm{h})$ in high bacteria, low bacteria and control treatments, respectively. On day 58, the first NPP negative values were recorded, which slowly decreased until the end of the experiment (Figure 4c). No statistically significant differences were observed between the different treatments for NPP $(p=0.55)$, GPP $(p=0.29)$ nor WCR $(p=0.30)$. Chla (Figure $4 \mathrm{~d}$ ) was below the detection limit in the first two weeks, increasing later to reach a maximum of 573.82, 460.16 and $703.58 \mu \mathrm{g} / \mathrm{L}$ in high bacteria, low bacteria and control treatments, respectively (between days 38 and 52). When the greenhouse was covered with the black shade cloth the concentration of Chla was stabilized around $150 \mu \mathrm{g} / \mathrm{L}$. When the black shade cloth was removed, day 136, a second Chl $a$ rise was observed. There were no statistically significant differences between treatments $(p=0.07)$ for this variable.

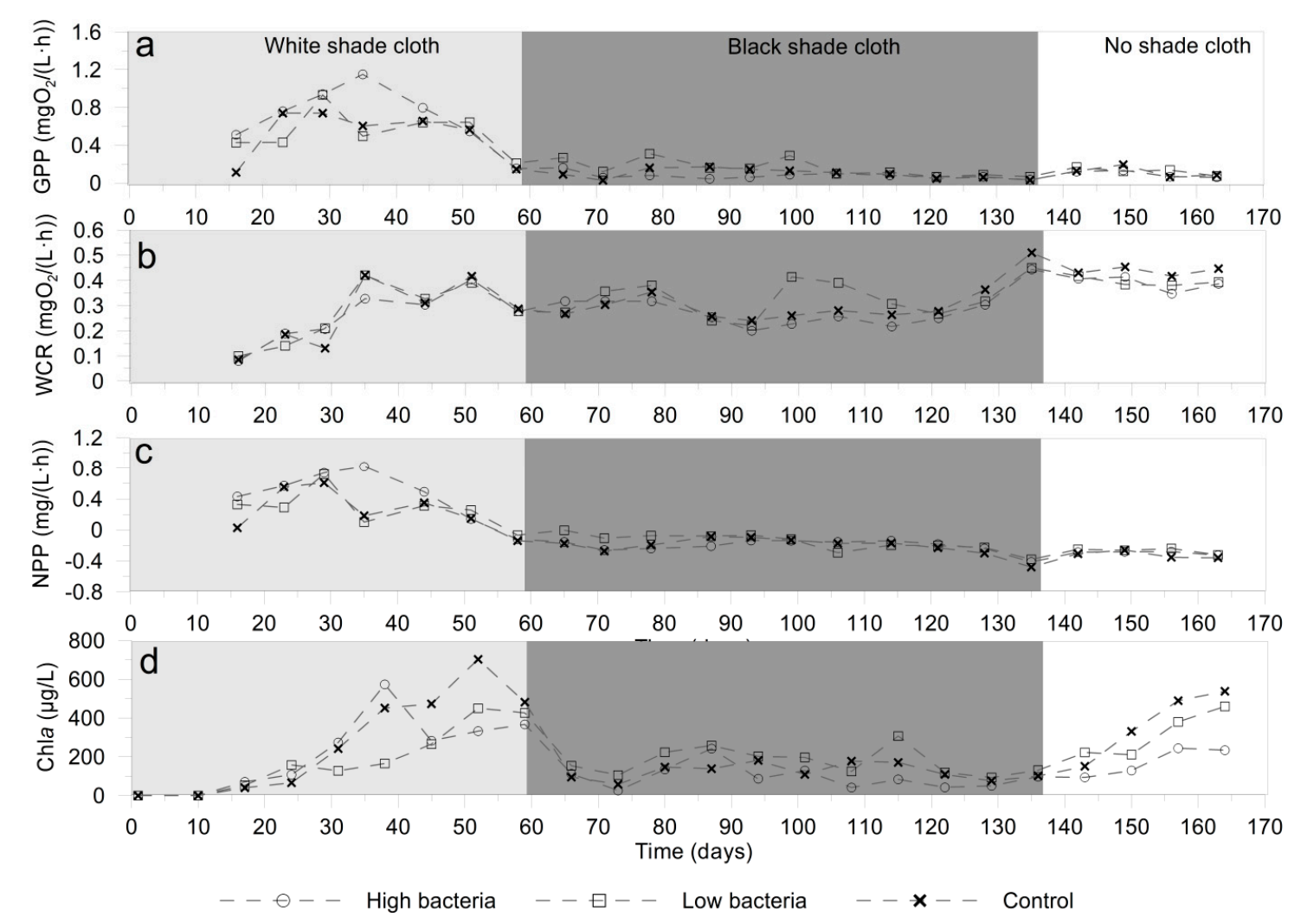

Figure 4. Evolution of microbial activity, (a) gross primary production, (b) water column respiration, (c) net primary production and (d) chlorophyll $a$. Each data represents the average of the three experimental units for high bacteria treatment $\left(2.8 \times 10^{4} \mathrm{cfu} / \mathrm{mL}\right)$, low bacteria treatment $\left(2.8 \times 10^{3} \mathrm{cfu} / \mathrm{mL}\right)$ and control treatment.

\subsection{Growth Parameters}

Shrimp growth was equal for all of the treatments (Figure 5). At the beginning of the experiment the shrimps weighed $0.0675 \pm 0.0433 \mathrm{~g}$ (initial biomass $13.5074 \mathrm{~g} / \mathrm{m}^{2}$ ). They grew up to $16.76 \pm 0.15$, $17.58 \pm 1.41$ and $17.94 \pm 0.65 \mathrm{~g}$ in high bacteria, low bacteria and control treatments, respectively. 


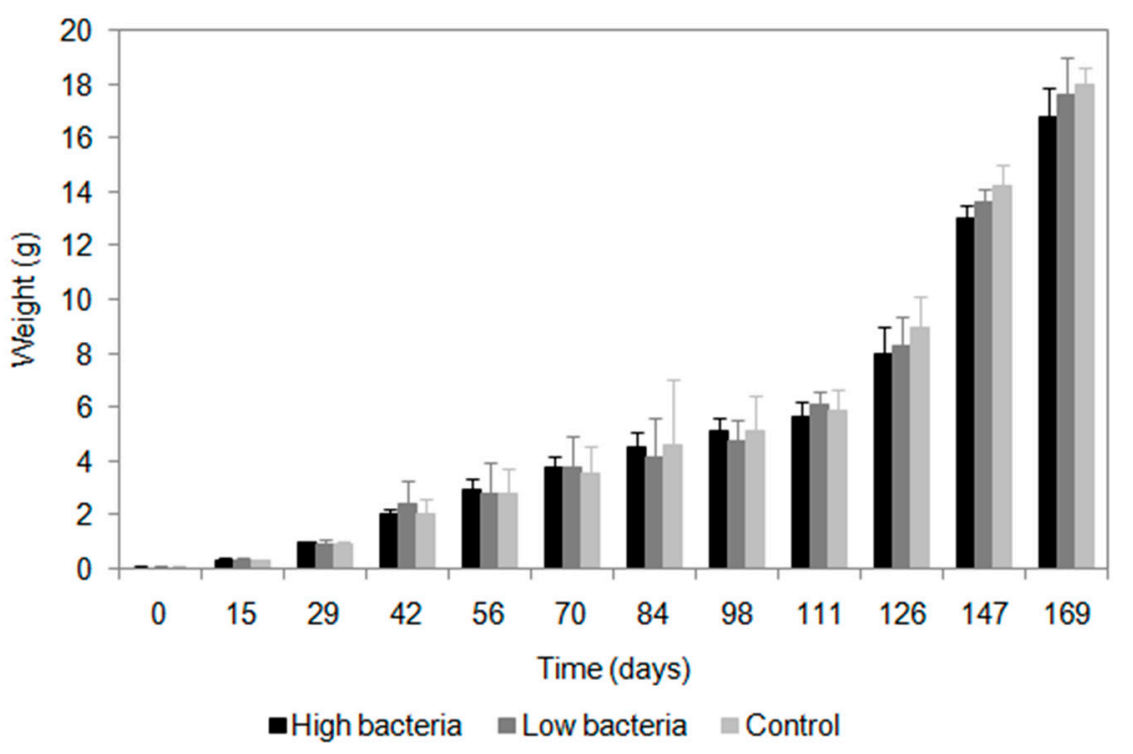

Figure 5. The shrimp weight gain. Each bar represents the average of the three experimental units for the high bacteria treatment $\left(2.8 \times 10^{4} \mathrm{cfu} / \mathrm{mL}\right)$, low bacteria treatment $\left(2.8 \times 10^{3} \mathrm{cfu} / \mathrm{mL}\right)$ and control treatment.

Weight gain, weekly weight gain, biomass gain, FCR and survival results are included in Table 2. ANOVA showed no statistically significant differences between the different treatments in these growth parameters.

\subsection{Immune System Parameters}

On day 86, within the immature system, our TPC was around $80-90 \mathrm{mg} / \mathrm{mL}$ in the shrimp hemolymph. Statistical analysis showed no significant differences between treatments $(p=0.65)$ (Table 3$)$. GH percentage was around 30 and $\mathrm{HH}$ was around $70 \%$ in the treatments with $B$. amyloliquefaciens. In the control treatment values were close to 25 and $75 \%$ for $\mathrm{GH}$ and $\mathrm{HH}$, respectively. This difference $(5 \%)$ between control and treatments with the probiotic is statistically significant $(p=0.04)$.

On day 169 , within the mature system, TPC in the hemolymph was around $120 \mathrm{mg} / \mathrm{mL}$ in all treatments $(p=0.93)$. The GH percentage was around 46 and the $\mathrm{HH}$ was around $54 \%$ in the treatments with $B$. amyloliquefaciens. In the control treatment, values were close to 39 and $61 \%$ for $\mathrm{GH}$ and $\mathrm{HH}$, respectively. This difference $(7 \%)$ between the control and treatments with the probiotic is statistically significant $(p=0.04)$.

\section{Discussion}

\subsection{Effects on the Biofloc System}

The experiment was carried out between spring and autumn in a Mediterranean climate area. In temperate climates, greenhouses are a good strategy to maintain water temperature, facilitating shrimp culture during the coldest months [52-54]. During the experiment the high environmental temperatures forced us to use a white shade cloth in spring and a black shade cloth in summer for temperature control inside the greenhouse. At the end of the experiment (autumn), the shade cloths were removed to avoid water cooling. Using different shade cloths to control the effect of environmental temperatures inside the greenhouse is usual [55], and thanks to them the water temperature was maintained within the adequate range for the cultivation of L. vannamei [35] in this experiment.

Dissolved oxygen remained above $5 \mathrm{mg} / \mathrm{L}$ and $85 \%$ saturation throughout the experiment, which are the recommended values by Cheng et al. [56]. Both the $\mathrm{pH}$ and the alkalinity decreased throughout the experiment, and this trend is common in BFT, due to the high metabolic rate of bacteria present in 
the system [39]. In spite of the fact that low alkalinity can negatively affect the nitrification process [57], the lowest levels were observed at the end of the experiment, just when the system was mature. In this moment, TAN and nitrites did not accumulate in the water column. This suggests that alkalinity did not affect the nitrification processes. Moreover, the addition of sodium bicarbonate and calcium hydroxide helped to maintain $\mathrm{pH}$ and alkalinity respectively within the optimal values determined by Van Wyk and Scarpa [35].

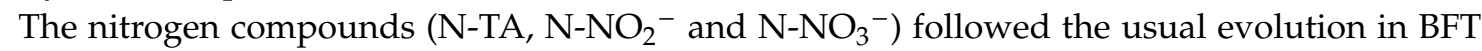
described by Avnimelech [2]. At the beginning of the experiment, N-TA was accumulated, which is typical of the immature BFT phase. When the bacterial nitrification started, N-TA was oxidized to $\mathrm{N}^{-\mathrm{NO}_{2}}{ }^{-}$, and then N-TA descended and an $\mathrm{N}-\mathrm{NO}_{2}{ }^{-}$peak appeared. Since day 115 , the peak of $\mathrm{N}-\mathrm{NO}_{2}{ }^{-}$disappeared and $\mathrm{N}-\mathrm{NO}_{3}{ }^{-}$was accumulated in water, indicating a mature BFT characterized

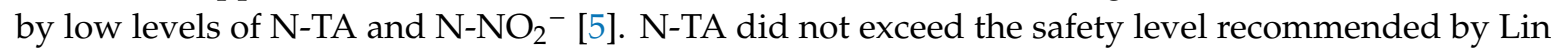

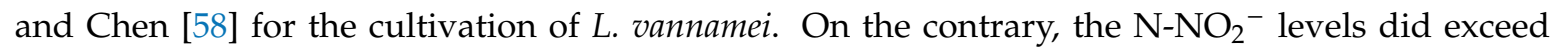
safety limits. According to Lin and Chen [40], exceeding the safety level $\left(15 \mathrm{mg} / \mathrm{L} \mathrm{N}-\mathrm{NO}_{2}{ }^{-}\right)$does not cause shrimp mortality, but prolonged exposure to high levels could cause it. In this experiment, the $15 \mathrm{mg} / \mathrm{L}$ limit of $\mathrm{N}^{-\mathrm{NO}_{2}}{ }^{-}$was exceeded for approximately 30-40 days, with a maximum value of $21.10 \mathrm{mg} / \mathrm{L}$. Xie et al. [27] observed under laboratory conditions, that germinated B. amyloliquefaciens could eliminate up to $10 \mathrm{mg} / \mathrm{L}$ of $\mathrm{N}_{-N_{2}}{ }^{-}$in 24 hours. Previous studies with mature biofloc systems did not find significant nitrite reductions, when the probiotic was applied directly to the water column. In this research we studied the effect during the maturation process of the biofloc, but we neither found a significant reduction of nitrites with respect to the control treatment $(p=0.05)$. $\mathrm{P}_{-} \mathrm{PO}_{4}{ }^{3-}$ and $\mathrm{N}^{-\mathrm{NO}_{3}}{ }^{-}$ were accumulated in water throughout the culture, following normal BFT dynamics and reaching levels similar to those observed in other experiments [38,59,60].

The evolution of TSS was similar to that observed by Gaona et al. [52] and Ray et al. [59]. In the final two weeks of the experiment, the TSS levels were slightly higher than the optimal value of $0.5 \mathrm{~g} / \mathrm{L}$ established by Samocha et al. [61] for the cultivation of L. vannamei. TSS reduction would reduce the amount of bacteria present in the system, and therefore reduce the consumption of dissolved oxygen [52]. In this experiment, since dissolved oxygen concentrations did not drop below $5 \mathrm{mg} / \mathrm{L}$, it was not necessary to use any solids removal techniques, which simplified culture management. The results obtained show that, as other probiotics [9], the application of the spores of B. amyloliquefaciens does not affect the dynamics of N-TA, N-NO ${ }_{2}^{-}, \mathrm{N}_{-} \mathrm{NO}_{3}{ }^{-}, \mathrm{P}_{-} \mathrm{PO}_{4}{ }^{3-}$ and TSS in biofloc systems.

Average Chl $a$ values were around $150 \mu \mathrm{g} / \mathrm{L}$, similar to those observed by other authors such as Liu et al. [62] and Martins et al. [63]. Maximum Chla concentration(703.58 $\mu \mathrm{g} / \mathrm{L})$ was higher than that found by Gaona et al. [52] and Emerenciano et al. [64] (500 $\mu \mathrm{g} / \mathrm{L})$, although it was below that observed by Schrader et al. [65]. Chla concentration in BFT is highly variable, and depends on environmental conditions and changes that occur in the BFT itself $[65,66]$. In this experiment, two Chla peaks were observed at the beginning and at the end of the experiment due to shade cloths management. The first peak was observed with the white shade cloth and the second when the shade cloths were removed. NPP, WCR and GPP dynamics are in agreement with those observed by Vinatea et al. [67], where the WCR increased and the GPP decreased, mainly during the first two months of culture. WCR values were similar to those observed by Vilani et al. [68], around $0.45 \mathrm{mg} \mathrm{O} /(\mathrm{L} \cdot \mathrm{h})$ and lower than those observed by Schveitzer et al. [42] and Vinatea et al. [67], who obtained values above $1 \mathrm{mg} \mathrm{O}_{2} /(\mathrm{L} \cdot \mathrm{h})$. NPP evolution shows the predominance of autotrophic processes in the BFT during the first culture weeks, characterized by lower oxygen consumption than production. Since day 58 a change of trophic state to a dominance of heterotrophic processes was observed. Chla evolution shows a second peak at the end of the experiment. This increase in Chla did not lead to an increase in GPP and NPP. Thus, the change in the trophic status of the BFT is attributed, not to the evolution of Chla, but to the evolution of the bacterial population. 
The beginning of nitrification processes by bacteria begins to generate a significant bacterial mass that causes heterotrophic processes to predominate in the culture system. WCR increases slowly over the weeks, at the same time as the TSS increases, which consume any water-dissolved oxygen [52].

\subsection{Effects on Shrimps}

The results showed a survival and a weekly weight increase around $60 \%$ and $0.7 \mathrm{~g} /$ week respectively, in all of the treatments, which was similar to those observed by other authors [43,69-71]. These low survival values are related to the increase of $\mathrm{N}^{-\mathrm{NO}_{2}}{ }^{-}$during an important phase of the culture. The long exposure of shrimps to high nitrites values forced us to reduce their feed to $60 \%$, which decreased the shrimp growth between days 70 and 110, as observed in Figure 5. During the period of peak ${\mathrm{N}-\mathrm{NO}_{2}}^{-}$, a few dead shrimps were observed in the feeders. This mortality could be a consequence of prolonged exposure to high levels of $\mathrm{N}^{-\mathrm{NO}_{2}}{ }^{-}$[40], which affected the final survival in all of the treatments equally. Authors such as Camacho [26] and Reda and Selim [72], applied B. amyloliquefaciens in a recirculation system, and observed improvements in the growth parameters due to the production of enzymes in the shrimp digestive system [13]. However, we have not observed this effect when applying this probiotic in BFT. It might be because the protein intake from the consumption of bioflocs [3] provides more nutritional benefits than the generation of digestive enzymes in the digestive tract of shrimp by B. amyloliquefaciens, not showing any difference between treatments.

During the experiment the immune system was analyzed when the BFT was in two different states, immature (day 86) and mature (day 169) biofloc. The percentages of granular and hyaline hemocytes in the hemolymph were within the range observed by different authors for L. vannamei [26,45-47]. In the first sampling, it was observed that the percentage of GH was 5\% higher in both treatments with B. amyloliquefaciens. In the second sampling, the difference between treatments with probiotic and control treatment was $7 \%$. These results show that the application of B. amyloliquefaciens increases the percentage of $\mathrm{GH}$ with respect to that of $\mathrm{HH}$. GH have different mechanisms of action against pathogens such as phagocytosis, encapsulation, cytotoxicity and the storage and release of prophenoloxidase into the system [73,74]. HH only fight pathogens by phagocytosis, making them less effective against pathogens [73,74]. When the biofloc system was immature, the level of nitrite was higher than safety.

The application of B. amyloliquefaciens significantly increased GH proportion in the hemolymph, and thereforeimproved the immune response capacity of the shrimp in high and low bacteria treatments. This effect was significant during the period when the biofloc was immature and the nitrite levels were high and produced stress to shrimp [40]. It is extremely valuable that this immune response could be achieved at the time of highest stress exposure amongst the shrimp, and might alleviate the negative effects of culture conditions, because shrimp were very sensitive to stress situations $[73,75]$.

A $7 \%$ increase in $\mathrm{GH}$ is comparable to that caused by other probiotics or food components $[9,69]$. In fact, Souza et al. [9] observed a similar increase in the percentage of granular hemocytes when they used a multi-species probiotic with a similar concentration (between $10^{3}$ and $10^{4} \mathrm{cfu} / \mathrm{mL}$ ). So, B. amyloliquefaciens has a better effect upon the immune system than other probiotics, and combining B. amyloliquefaciens with other probiotic strains may extend the benefits over shrimp cultured in BFT. B. amyloliquefaciens has the appropriate characteristics to be considered as a probiotic for the culture of shrimps in BFT, as a preventive measure to the appearance of possible diseases.

The TPC observed was similar to that observed in L. vannamei by other researchers [26,45-47]. In this variable no statistically significant differences were observed between the treatments in any of the samples. Previously unpublished research by F. Llario observed an improvement in TPC when applying B. amyloliquefaciens in a mature BFT. The stress produced during the maturation of the BFT could have affected to a greater extent the TPC than the probiotic, masking the effects of B. amyloliquefaciens on this variable. Among the functions of the proteins in the hemolymph is the recognition of pathogens, their inhibition and their agglutination, so that they can be eliminated by the hemocytes [74], being a variable widely used to monitor the state of the immune system $[46,47]$. 
If we compare the results in the immune system between the mature and immature stage of BFT (obviating the dose of probiotic received), it is appreciated that the GH values increased $15 \%$ with the maturation of the BFT $(p=0.00)$. Also, TPC increased $34 \mathrm{mg} / \mathrm{mL}(p=0.00)$ from day 86 to 169. Although shrimp growth could positively affect TPC levels [75], the maturation of BFT and the elimination of $\mathrm{N}^{-\mathrm{NO}_{2}}{ }^{-}$by BFT bacteria causes improvements in the shrimp immune system $[48,49,75]$. In this experiment, it is shown that the effect of probiotics does complement that of BFT. The role of B. amyloliquefaciens is of great importance mainly during the maturation of BFT, because it provides a reinforcement of the immune system that could help the shrimps to fight against possible pathogens.

The different doses of $B$. amyloliquefaciens tested (high bacteria treatment $\left(2.8 \times 10^{4} \mathrm{cfu} / \mathrm{mL}\right)$ and low bacteria treatment $\left.\left(2.8 \times 10^{3} \mathrm{cfu} / \mathrm{mL}\right)\right)$, did not produce significant differences. This shows that B. amyloliquefaciens is effective, when applied to water, at a dose of at least $10^{3} \mathrm{cfu} / \mathrm{mL}$, doses clearly lower than those used by other authors in shrimp culture [8,9].

\section{Conclusions}

Despite the good characteristics of B. amyloliquefaciens as a biofloc promoter bacterium, its direct application in the water column did not have a significant effect upon water quality. The addition of $B$. amyloliquefaciens to the water column, during the maturation process of the biofloc, did not produce significant changes on nutrient dynamics, nor a significant reduction of nitrites with respect to our control treatment. Further studies are necessary to analyze whether improving the application technique in water can enhance their effect. The addition of the probiotic also failed to alter the trophic state of the system, or to influence the Chla levels.

There was also no significant effect on the growth parameters when applying the probiotic bacteria. These results seem to indicate that the nutritional improvements of the biofloc system surpass those that B. amyloliquefaciens could have. However, where this bacterium can play a very important role, it is in the reinforcement of the shrimp immune system, mainly under unfavorable culture conditions, such as an immature biofloc system. B. amyloliquefaciens manages to increase the percentage of $\mathrm{GH}$, both in mature and immature BFT, although the increase in GH that a mature BFT provides is more important than that produced by the probiotic. In addition, it has been observed that B. amyloliquefaciens is effective for the immune system at a dose of $10^{3} \mathrm{cfu} / \mathrm{mL}$, a dose lower than that recommended for other probiotics, reducing costs and maintaining the benefits on the system. However, we cannot exclude that higher doses could have an effect on water quality.

Author Contributions: F.L., M.R. and L.H.P. designed the experiment, F.L., S.F., M.-T.S.-F., J.E. and M.R. participated in the experiment, sampling and analyses. F.L., S.F., M.-T.S.-F., M.R. and L.H.P. interpreted the data. F.L., S.F. and M.-T.S.-F. wrote the manuscript. All the authors read and approved the final manuscript.

Funding: This research has been funded by the pre-doctoral program VALi + D from the Conselleria d'Educació, Investigació, Cultura i Esports (Generalitat Valenciana), file number ACIF/2014/244.

Acknowledgments: We wish to thank the collaboration of Álvaro Ortíz from the company Evonik, for his contribution in the experimental design and the supply of Ecobiol Plus ${ }^{\circledR}$. Also thank Michaël Metz of the company Le Gouessant, for the selfless feed supply. Finally thank Ivan Vidal and Langostinos el Real for their help in obtaining the shrimps for this experiment.

Conflicts of Interest: The authors declare that they have no conflict of interest.

Ethical Statement: All applicable institutional guidelines for the care and use of animals were followed by the authors.

\section{References}

1. Emerenciano, M.; Gaxiola, G.; Cuzon, G. Biofloc technology (BFT): A review for aquaculture application and animal food industry. In Biomass Now-Cultivation and Utilization; Darko, M., Ed.; InTech, Queen's University: Kingston, ON, Canada, 2013; pp. 301-328.

2. Avnimelech, Y. Biofloc Technology: A Practical Guide Book, 1st ed.; World Aquaculture Society: Baton Rouge, LA, USA, 2009. 
3. Crab, R.; Defoirdt, T.; Bossier, P.; Verstraete, W. Biofloc technology in aquaculture: Beneficial effects and future challenges. Aquaculture 2012, 356, 351-356. [CrossRef]

4. Wasielesky, W.; Atwood, H.; Stokes, A.; Browdy, C.L. Effect of natural production in a zero exchange suspended microbial floc based super-intensive culture system for white shrimp Litopenaeus vannamei. Aquaculture 2006, 258, 396-403. [CrossRef]

5. Jatobá, A.; Silva, B.C.; Silva, J.S.; Vieira, F.D.; Mouriño, J.L.; Seiffert, W.Q.; Toledo, T.M. Protein levels for Litopenaeus vannamei in semi-intensive and biofloc systems. Aquaculture 2014, 432, 365-371. [CrossRef]

6. Xu, W.; Morris, T.C.; Samocha, T.M. Effects of C/N ratio on biofloc development, water quality, and performance of Litopenaeus vannamei juveniles in a biofloc-based, high-density, zero-exchange, outdoor tank system. Aquaculture 2016, 453, 169-175. [CrossRef]

7. Sanders, M.E. Probiotics: Definition, sources, selection, and uses. Clin. Infect. Dis. 2008, 46, 58-61. [CrossRef]

8. Van Hai, N.; Fotedar, R.A. Review of probiotics in shrimp aquaculture. J. Appl. Aquac. 2010, 22, $251-266$. [CrossRef]

9. Souza, D.M.; Suita, S.M.; Leite, F.P.; Romano, L.A.; Wasielesky, W.; Ballester, E.L. The use of probiotics during the nursery rearing of the pink shrimp Farfantepenaeus brasiliensis (Latreille, 1817) in a zero exchange system. Aquac. Res. 2012, 43, 1828-1837. [CrossRef]

10. Krummenauer, D.; Poersch, L.; Romano, L.A.; Lara, G.R.; Encarnação, P.; Wasielesky, W. The effect of probiotics in a Litopenaeus vannamei biofloc culture system infected with Vibrio parahaemolyticus. J. Appl. Aquac. 2014, 26, 370-379. [CrossRef]

11. Farzanfar, A. The use of probiotics in shrimp aquaculture. Pathog. Dis. 2006, 48, 149-158.

12. Zhou, X.; Wang, Y.; Li, W. Effect of probiotic on larvae shrimp (Penaeus vannamei) based on water quality, survival rate and digestive enzyme activities. Aquaculture 2009, 287, 349-353. [CrossRef]

13. Nuez-Ortín, W.G.; Casillas-Hernández, R.; Nolasco-Soria, H. Efecto de Ecobiol Aqua en la Actividad Enzimática del Camarón. Aquafeed, 2013. Available online: www.aquafeed.co/efecto-de-ecobiol-aqua-enla-actividad-enzimatica-del-camaron/ (accessed on 17 April 2018).

14. Pandiyan, P.; Balaraman, D.; Thirunavukkarasu, R.; George, E.G.; Subaramaniyan, K.; Manikkam, S.; Sadayappan, B. Probiotics in aquaculture. Drug Invent. Today 2013, 5, 5-59. [CrossRef]

15. Rengpipat, S.; Rukpratanporn, S.; Piyatiratitivorakul, S.; Menasaveta, P. Immunity enhancement in black tiger shrimp (Penaeus monodon) by a probiont bacterium (Bacillus S11). Aquaculture 2000, 191, 271-288. [CrossRef]

16. Tseng, D.Y.; Ho, P.L.; Huang, S.Y.; Cheng, S.C.; Shiu, Y.L.; Chiu, C.S.; Liu, C.H. Enhancement of immunity and disease resistance in the white shrimp, Litopenaeus vannamei, by the probiotic, Bacillus subtilis E20. Fish Shellfish Immunol. 2009, 26, 339-344. [CrossRef]

17. Paiva-Maia, E.; Alves-Modesto, G.; Otavio-Brito, L.; Olivera, A.; Vasconcelos-Gesteira, T.C. Effect of a commercial probiotic on bacterial and phytoplankton concentration in intensive shrimp farming (Litopenaeus vannamei) recirculation systems. Lat. Am. J. Aquat. Res. 2013, 41, 126-137. [CrossRef]

18. Vargas-Albores, F.; Porchas-Cornejo, M.A.; Martínez-Porchas, M.; Villalpando-Canchola, E.; Gollas-Galván, T.; Martínez-Córdova, L.R. Bacterial biota of shrimp intestine is significantly modified by the use of a probiotic mixture: A high throughput sequencing approach. Helgol. Mar. Res. 2017, 71, 1-10. [CrossRef]

19. Dalmin, G.; Kathiresan, K.; Purushothaman, A. Effect of probiotics on bacterial population and health status of shrimp in culture pond ecosystem. Indian J. Exp. Biol. 2001, 39, 939-942.

20. Nimrat, S.; Suksawat, S.; Boonthai, T.; Vuthiphandchai, V. Potential Bacillus probiotics enhance bacterial numbers, water quality and growth during early development of white shrimp (Litopenaeus vannamei). Vet. Microbiol. 2012, 159, 443-450. [CrossRef]

21. Ramezani-Fard, E.; Zokaeifar, H.; Ebrahimi, M.; Kamarudin, M.S.; Goh, Y.M. Probiotic administration of Litopenaeus vannamei: Is there any negative effect on the fatty acid profile of meat? Iran. J. Fish. Sci. 2014, 13, 550-559.

22. Jerzsele, A.; Szeker, K.; Csizinszky, R.; Gere, E.; Jakab, C.; Mallo, J.J.; Galfi, P. Efficacy of protected sodium butyrate, a protected blend of essential oils, their combination, and Bacillus amyloliquefaciens spore suspension against artificially induced necrotic enteritis in broilers. Poult. Sci. 2012, 91, 837-843. [CrossRef]

23. Ahmed, S.T.; Islam, M.M.; Mun, H.S.; Sim, H.J.; Kim, Y.J.; Yang, C.J. Effects of Bacillus amyloliquefaciens as a probiotic strain on growth performance, cecal microflora, and fecal noxious gas emissions of broiler chickens. Poult. Sci. 2014, 93, 1963-1971. [CrossRef] 
24. Larsen, N.; Thorsen, L.; Kpikpi, E.N.; Stuer-Lauridsen, B.; Cantor, M.D.; Nielsen, B.; Brockmann, E.; Derkx, P.M.; Jespersen, L. Characterization of Bacillus spp. strains for use as probiotic additives in pig feed. Appl. Microbiol. Biotechnol. 2014, 98, 1105-1118. [CrossRef]

25. Lei, X.; Piao, X.; Ru, Y.; Zhang, H.; Péron, A.; Zhang, H. Effect of Bacillus amyloliquefaciens-based direct-fed microbial on performance, nutrient utilization, intestinal morphology and cecal microflora in broiler Chickens. Asian Australas. J. Anim. 2015, 28, 239-246. [CrossRef]

26. Camacho, M.A. Efecto de la Aplicación de Probióticos en Dietas Para Camarón Blanco Litopenaeus vannamei, Mediante Indicadores de Crecimientoy Respuesta Inmune. Master's Thesis, Instituto Tecnológico de Sonora, Sonora, Mexico, 2012.

27. Xie, F.; Zhu, T.; Zhang, F.; Zhou, K.; Zhao, Y.; Li, Z. Using Bacillus amyloliquefaciens for remediation of aquaculture water. Springer Plus 2013, 2, 119. [CrossRef]

28. Huang, L.; Ran, C.; He, S.; Ren, P.; Hu, J.; Zhao, X.; Zhou, Z. Effects of dietary Saccharomyces cerevisiae culture or live cells with Bacillus amyloliquefaciens spores on growth performance, gut mucosal morphology, hsp70 gene expression, and disease resistance of juvenile common carp (Cyprinus carpio). Aquaculture 2015, 438, 33-38. [CrossRef]

29. Saputra, F.; Shiu, Y.; Chen, Y.; Puspitasari, A.W.; Danata, R.H.; Liu, C.; Hu, S. Dietary supplementation with xylanase-expressing B. amyloliquefaciens R8 improves growth performance and enhances immunity against Aeromonas hydrophila in Nile tilapia (Oreochromis niloticus). Fish Shellfish Immunol. 2016, 58, 397-405. [CrossRef]

30. World Organisation for Animal Health. Manual of Diagnostic Tests for Aquatic Animals. OiE, 2016. Available online: www.oie.int/en/standard-setting/aquatic-manual/access-online/ (accessed on 19 November 2018).

31. Jory, D.E.; Cabrera, T.R.; Dugger, D.M.; Fegan, D.; Lee, P.G.; Lawrence, L.; Jackson, C.; Mcintosh, R.; Castañeda, J.; International, B.; et al. A global Review of shrimp feed management: Status and perspectives. In Aquaculture 2001: Book of Abstracts, 1st ed.; World Aquaculture Society, Ed.; World Aquaculture Society: Baton Rouge, LA, USA, 2001.

32. Baumgarten, M.G.Z.; Wallner-Kersanach, M.; Niencheski, L.F.H. Manual de Análisis em Oceanografía Química, 1st ed.; Editora da FURG: Rio Grande, Brazil, 2010.

33. Grasshoff, K. Methods of Seawater Analysis, 1st ed.; WILEY-VCH: Weinheim, Germany, 1976.

34. Murphy, J.; Riley, J. A modified single solution method for the determination of phosphate in natural waters. Anal. Chim. Acta 1962, 27, 31-36. [CrossRef]

35. Van Wyk, P.; Scarpa, J. Water quality requirements and management. In Farming Marine Shrimp in Recirculating Freshwater Systems, 1st ed.; Florida Department of Agriculture and Consumer Services, Ed.; Harbor Branch Oceanographic Institution: Fort Pierce, FL, USA, 1999.

36. AVAMET. Associació Valenciana de Meteorologia Josep Peinado. AVAMET, 2017. Available online: www.avamet.org (accessed on 21 December 2017).

37. Furtado, P.S.; Gaona, C.A.; Poersch, L.H.; Wasielesky, W. Application of different doses of calcium hydroxide in the farming shrimp Litopenaeus vannamei with the biofloc technology (BFT). Aquac. Int. 2014, 22, 1009-1023. [CrossRef]

38. Furtado, P.S.; Poersch, L.H.; Wasielesky, W. Effect of calcium hydroxide, carbonate and sodium bicarbonate on water quality and zootechnical performance of shrimp Litopenaeus vannamei reared in bio-flocs technology (BFT) systems. Aquaculture 2011, 321, 130-135. [CrossRef]

39. Ebeling, J.M.; Timmons, M.B.; Bisogni, J. Engineering analysis of the stoichiometry of photoautotrophic, autotrophic, and heterotrophic removal of ammonia-nitrogen in aquaculture systems. Aquaculture 2006, 257, 346-358. [CrossRef]

40. Lin, Y.; Chen, J. Acute toxicity of nitrite on Litopenaeus vannamei (Boone) juveniles at different salinity levels. Aquaculture 2003, 224, 193-201. [CrossRef]

41. Wright, S.; Jeffrey, S.; Mantoura, R.; Llewellyn, C.; Bjornland, T.; Repeta, D.; Welschmeyer, N. Improved HPLC method for the analysis of chlorophylls and carotenoids from marine phytoplankton. Mar. Ecol. Prog. Ser. 1991, 77, 183-196. [CrossRef]

42. Hooker, S.; Firestone, E.; Claustre, H.; Ras, J. The First SeaWiFS HPLC Analysis Round-Robin Experiment (SeaHARRE-1). NASA Technical Reports Server, 2001. Available online: https://ntrs.nasa.gov/search.jsp?R= 20010072242 (accessed on 18 December 2017). 
43. Schveitzer, R.; Arantes, R.; Costódio, P.F.; Santo, C.M.; Arana, L.V.; Seiffert, W.Q.; Andreatta, E.R. Effect of different biofloc levels on microbial activity, water quality and performance of Litopenaeus vannamei in a tank system operated with no water exchange. Aquac. Eng. 2013, 56, 59-70. [CrossRef]

44. Dodds, W.K.; Cole, J.J. Expanding the concept of trophic state in aquatic ecosystems: It's not just the autotrophs. Aquat. Sci. 2007, 69, 427-439. [CrossRef]

45. Maggioni, D.S.; Andreatta, E.R.; Hermes, E.M.; Barracco, M.A. Evaluation of some hemato-immunological parameters in female shrimp Litopenaeus vannamei submitted to unilateral eyestalk ablation in association with a diet supplemented with superdoses of ascorbic acid as a form of immunostimulation. Aquaculture 2004, 241, 501-515. [CrossRef]

46. Li, K.; Zheng, T.; Tian, Y.; Xi, F.; Yuan, J.; Zhang, G.; Hong, H. Beneficial effects of Bacillus licheniformis on the intestinal microflora and immunity of the white shrimp, Litopenaeus vannamei. Biotechnol. Lett. 2007, 29, 525-530. [CrossRef]

47. Macias-Sancho, J.; Poersch, L.H.; Bauer, W.; Romano, L.A.; Wasielesky, W.; Tesser, M.B. Fishmeal substitution with Arthrospira (Spirulina platensis) in a practical diet for Litopenaeus vannamei: Effects on growth and immunological parameters. Aquaculture 2014, 426, 120-125. [CrossRef]

48. Souza, D.M.; Borges, V.D.; Furtado, P.; Romano, L.A.; Wasielesky, W.; Monserrat, J.M.; Garcia, L.D. Antioxidant enzyme activities and immunological system analysis of Litopenaeus vannamei reared in biofloc technology (BFT) at different water temperatures. Aquaculture 2016, 451, 436-443. [CrossRef]

49. Ekasari, J.; Azhar, M.H.; Surawidjaja, E.H.; Nuryati, S.; Schryver, P.D.; Bossier, P. Immune response and disease resistance of shrimp fed biofloc grown on different carbon sources. Fish Shellfish Immunol. 2014, 41, 332-339. [CrossRef]

50. Xu, W.J.; Pan, L.Q. Evaluation of dietary protein level on selected parameters of immune and antioxidant systems, and growth performance of juvenile Litopenaeus vannamei reared in zero-water exchange biofloc-based culture tanks. Aquaculture 2014, 426, 181-188. [CrossRef]

51. Lowry, O.H.; Rosebrough, N.J.; Farr, A.L.; Randall, R.J. Protein measurement with the Folin phenol reagent. J. Biol. Chem. 1955, 193, 265-275.

52. Gaona, C.A.P.; Poersch, L.H.; Krummenauer, D.; Foes, G.K.; Wasielesky, W.J.; Wasielesky, W. The effect of solids removal on water quality, growth and survival of Litopenaeus vannamei in a biofloc technology culture system. Int. J. Recirc. Aquac. 2011, 12, 1-12. [CrossRef]

53. Ray, A.J. Study shows lower biofloc concentration may improve shrimp production. Glob. Aquac. Advocate 2012, 15, 28-31.

54. Toledo, T.M.; Silva, B.C.; Vieira, F.N.; Mouriño, J.L.P.; Seiffert, W.Q. Effects of different dietary lipid levels and fatty acids profile in the culture of white shrimp Litopenaeus vannamei (Boone) in biofloc technology: Water quality, biofloc composition, growth and health. Aquac. Res. 2016, 47, 1841-1851. [CrossRef]

55. Montero, J.I. Tendencias tecnológicas en los invernaderos mediterráneos. In Manejo Del Clima en el Invernadero Mediterráneo, 1st ed.; Sánchez-Guerrero, M.C., Alonso, F.J., Lorenzo, P., Medrano, E., Eds.; Intituto de Invetigación y Formación Agraria y Pesquera: Seville, Spain, 2009; pp. 115-127.

56. Cheng, W.; Liu, C.; Kuo, C. Effects of dissolved oxygen on hemolymph parameters of freshwater giant prawn, Macrobrachium rosenbergii (de Man). Aquaculture 2003, 220, 843-856. [CrossRef]

57. Furtado, P.S.; Poersch, L.H.; Wasielesky, W. The effects of different alkalinity levels on Litopenaeus vannamei reared with biofloc Technology (BFT). Aquac. Int. 2015, 23, 345-358. [CrossRef]

58. Lin, Y.; Chen, J. Acute toxicity of ammonia on Litopenaeus vannamei (Boone) juveniles at different salinity levels. J. Exp. Mar. Biol. Ecol. 2001, 259, 109-119. [CrossRef]

59. Ray, A.J.; Lewis, B.L.; Browdy, C.L.; Leffler, J.W. Suspended solids removal to improve shrimp (Litopenaeus vannamei) production and an evaluation of a plant-based feed in minimal-exchange, superintensive culture systems. Aquaculture 2010, 299, 89-98. [CrossRef]

60. Correia, E.S.; Wilkenfeld, J.S.; Morris, T.C.; Wei, L.; Prangnell, D.I.; Samocha, T.M. Intensive nursery production of the Pacific white shrimp Litopenaeus vannamei using two commercial feeds with high and low protein content in a biofloc-dominated system. Aquac. Eng. 2014, 59, 48-54. [CrossRef]

61. Samocha, T.M.; Patnaik, S.; Speed, M.; Ali, A.; Burger, J.M.; Almeida, R.V.; Ayub, Z.; Harisanto, M.; Horowitz, A.; Brock, D.L. Use of molasses as carbon source in limited discharge nursery and grow-out systems for Litopenaeus vannamei. Aquac. Eng. 2007, 36, 184-191. [CrossRef] 
62. Liu, L.; Hu, Z.; Dai, X.; Avnimelech, Y. Effects of addition of maize starch on the yield, water quality and formation of bioflocs in an integrated shrimp culture system. Aquaculture 2014, 418, 79-86. [CrossRef]

63. Martins, T.G.; Odebrecht, C.; Jensen, L.V.; D'Oca, M.G.; Wasielesky, W. The contribution of diatoms to bioflocs lipid content and the performance of juvenile Litopenaeus vannamei (Boone, 1931) in a BFT culture system. Aquac. Res. 2016, 47, 1315-1326. [CrossRef]

64. Emerenciano, M.; Cuzon, G.; Arévalo, M.; Gaxiola, G. Biofloc technology in intensive broodstock farming of the pink shrimp Farfantepenaeus duorarum: Spawning performance, biochemical composition and fatty acid profile of eggs. Aquac. Res. 2014, 45, 1713-1726. [CrossRef]

65. Schrader, K.K.; Green, B.W.; Perschbacher, P.W. Development of phytoplankton communities and common off-flavors in a biofloc technology system used for the culture of channel catfish (Ictalurus punctatus). Aquac. Eng. 2011, 45, 118-126. [CrossRef]

66. Llario, F.; Rodilla, M.; Escrivá, J.; Falco, S.; Sebastiá-Frasquet, M.T. Phytoplankton evolution during the creation of a biofloc system for shrimp culture. Int. J. Environ. Sci. Technol. 2019, 16, 211-222. [CrossRef]

67. Vinatea, L.; Gálvez, A.O.; Browdy, C.L.; Stokes, A.; Venero, J.; Haveman, J.; Lewis, B.L.; Lawson, A.; Shuler, A.; Leffler, J.W. Photosynthesis, water respiration and growth performance of Litopenaeus vannamei in a super-intensive raceway culture with zero water exchange: Interaction of water quality variables. Aquac. Eng. 2010, 42, 17-24. [CrossRef]

68. Vilani, F.G.; Schveitzer, R.; Fonseca-Arantes, R.; Vieira, F.; Espírito Santo, C.M.; Seiffert, W.Q. Strategies for water preparation in a biofloc system: Effects of carbon source and fertilization dose on water quality and shrimp performance. Aquac. Eng. 2016, 74, 70-75. [CrossRef]

69. Krummenauer, D.; Peixoto, S.; Cavalli, R.O.; Poersch, L.H.; Wasielesky, W. Superintensive culture of white shrimp, Litopenaeus vannamei, in a biofloc technology system in southern Brazil at different stocking densities. J. World Aquac. Soc. 2011, 42, 726-733. [CrossRef]

70. Ray, A.J.; Dillon, K.S.; Lotz, J.M. Water quality dynamics and shrimp (Litopenaeus vannamei) production in intensive, mesohaline culture systems with two levels of biofloc management. Aquac. Eng. 2011, 45, 127-136. [CrossRef]

71. Baloi, M.; Arantes, R.; Schveitzer, R.; Magnotti, C.; Vinatea, L. Performance of Pacific white shrimp Litopenaeus vannamei raised in biofloc systems with varying levels of light exposure. Aquac. Eng. 2013, 52, 39-44. [CrossRef]

72. Reda, R.M.; Selim, K.M. Evaluation of Bacillus amyloliquefaciens on the growth performance, intestinal morphology, hematology and body composition of Nile tilapia, Oreochromis niloticus. Aquac. Int. 2015, 23, 203-217. [CrossRef]

73. Johansson, M.W.; Keyser, P.; Sritunyalucksana, K.; Söderhäll, K. Crustacean haemocytes and haematopoiesis. Aquaculture 2000, 191, 45-52. [CrossRef]

74. Cuéllar-Anjel, J. Métodos de diagnósticos de enfermedades en camarones marinos de cultivo. In Guía Técnica: Patología e Inmunología de Camarones Peneidos, 1st ed.; Morales, V., Cuéllar-Anjel, J., Eds.; Programa CYTED Red II-D Vannamei: City of Panama, Panama, 2008; pp. 1-54.

75. Guo, H.; Xian, J.A.; Li, B.; Ye, C.X.; Wang, A.L.; Miao, Y.T.; Liao, S.A. Gene expression of apoptosis-related genes, stress protein and antioxidant enzymes in hemocytes of white shrimp Litopenaeus vannamei under nitrite stress. Comp. Biochem. Phys. C 2013, 157, 366-371. [CrossRef]

(C) 2019 by the authors. Licensee MDPI, Basel, Switzerland. This article is an open access article distributed under the terms and conditions of the Creative Commons Attribution (CC BY) license (http://creativecommons.org/licenses/by/4.0/). 